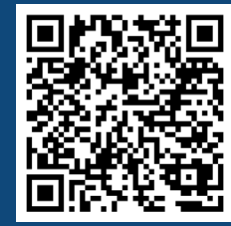

Keywords:

Incentive

Policy

Wooden house

Sectorial survey

Interview

Timber industry Received 03/07/2019 Accepted 27/I I/2019

Correspondence: engim.victor@yahoo.de

Victor A. De Araujo ${ }^{1 a+}$, Elen A. M. Morales ${ }^{2 a}$, Juliana Cortez-Barbosa ${ }^{2 b}$, Maristela Gava ${ }^{2 c}$, José N. Garcia ${ }^{3 a}$

\title{
PUBLIC SUPPORT FOR TIMBER HOUSING PRODUCTION IN BRAZIL
}

DE ARAUJO, V. A.; MORALES, E. A. M.; CORTEZ-BARBOSA, J.; GAVA, M.; GARCIA, J. N. Public support for timber housing production in Brazil. CERNE, v. 25, n. 4, p.365-374, 2019.

\section{HIGHLIGHTS}

Public policies have been apparently restrictive for timber construction in Brazil.

Public funding to develop businesses is not accessible to timber house industry.

Financial incentive is required to stimulate sustainable timber houses in Brazil.

Brazilian timber housing sector still depends on incentives to own promotion.

Brazil needs new housing policies suitable for greener and sustainable houses.

\section{ABSTRACT}

Using face-to-face interviews and semi-structured questionnaires with timber housing developers, this study assed the perceptions of respective industries about government stimuli and public policies towards timber construction in Brazil. Four questions were developed under qualitative aspects, which were percentually measured to enable a response comparative. Thereby, 107 of 210 companies were evaluated here. Under statistical view, this sampling revealed a margin of error acceptable and next to the ideal condition. Results suggest that current policies have been apparently restrictive. Timber house producers still are dependant on strategies for whole national segments, whose scope does not promote both local cleaner industries and those focused on sustainable solutions such as from this studied sector. Tax cuts and exemptions for greener products could be an efficient alternative to incentive this production sector, and promote these sustainable timber houses. The creation of assertive public policies could attract more investors and developers to expand this industry and other forest-timber sectors and, consequently, contribute to reduce the housing shortage in Brazil. 


\section{INTRODUCTION}

Diversification of the wood utilisation is gaining importance worldwide, whereas replaces nonrenewable resources (Longue Jr and Colodette, 20I3). Contemporary default construction raw materials - namely concrete and steel - are the main carbon generators, and then, timber product utilization provides a technically, economically and environmentally viable alternative (Xia et al. 20I4).

Wood-based constructions have secular applications, but only recently have scientists and professionals begun to recognize their potential to stave off global warming (Tollefson, 2017). Timber housing emerges as the most valuable and viable alternative to replace masonry houses (De Araujo et al., 20 I6b).

\section{THEORETICAL BACKGROUND ABOUT THE INDUSTRIAL SCOPE}

\section{Governmental support for construction industry in Brazil}

Housing shortage is a greater public challenge in Brazil, not only in terms of the need to supply the required number of dwellings (Berr et al., 20I5). Local housing policies have proven to be not so effective, since the intention to fulfil social functions does not materialize into actions (Ribeiro and Moreira, 20I4).

Civil construction industry has been stagnant for 20 years in Brazil. Policies of innovation are still being developed, and their effect on the industry is much smaller than that observed in other fields. But, socialeconomic and housing policies seem to demonstrate a greater importance over the evolution of building technologies, but they have generated contradictory tendencies (Castro and von Kruger, 20I3).

The dominance of masonry housing and the few stimuli to modernise the whole construction sector by means of sustainable techniques based on renewable materials are typical of the current situation.

Government support for the timber construction industry in Brazil

Timber industry focussed on construction carries typical features to forest chain or, in other words, this activity depends on stimuli for its own development in Brazil. Regardless the building technique, Batista and Ghavami (2005) stated that Brazilian houses are traditionally produced on their sites.
Similar to the Brazilian civil construction industry, Machado and Carvalho (2006) realized that local wood chain comprises several small-sized companies. This fact is suchlike the timber housing production sector, as suggested De Araujo et al. (2018a,b), which has concentrated relatively low investment due to compact-sized producers. Because of the lack of investment, Brazilian timber companies still employ, according to Murara Jr. et al. (20I3), obsolete technology, and low-yield machinery. However, from investments in innovative technologies, the products from forest-timber industry will need to be developed in order to make benefits for society (Ibá, 2017). For technological advances, the access to credit is required to acquire modern machines, technologies, plant expansions, labour training, etc. Incentives could allocate additional finance for such improvements.

On a path which the state needs to take the lead for development of any industrial sector as suggested by Lin and Chang (2009), government subsidies are possible mechanisms for encouraging innovation, in view of market failures.

Many products are dependent on construction market. In reason of civil construction growth, there are increases in the consumption of: structural parts, panels, furniture (Barbu and Paulitsch, 2015), and floors (Oliveira et al., 2019).

Despite the potential in the last decades, Brazilian forestry sector is still treated in an inadequate and unfair activity (Carvalho et al., 20I5).

Raw material production must be presented as another central factor to be more explored by the Brazilian government for the manufactured products.

Recently, Stephens and Grist (2014) stated that reforestations have increased globally in area, and are used for wood production and ecosystem services for biodiversity and soil conservation. In contrast, Brazil still is stagnant. Bacha (200I) had formerly proposed that it is essentially important to define public policies to encourage reforestation, especially, for small and medium-sized farmers.

Several successful applications of wood from plantation forests for building production in developed countries have enabled technological development for civil construction, expanding their utilisation possibilities (Santos and Aguilar, 2007).

Timber production for the construction industry is performed without an effective inclusion in the Brazilian public policies, while most of the local plantations are directed towards other purposes. According to IBÁ (2019), the Brazilian forests are essentially allocated to produce pulp and paper, lumber, charcoal, panels and laminated floors. 


\section{THEORETICAL BACKGROUND APPLIED METHODOLOGY}

\section{Survey research concepts}

Social field forms an important category of science that aims to study the behaviour of population or groups such as societies, businesses, economies, etc. (Bhattacherjee, 20I2). Such studies can contribute with industrial development, sharing discussions based on aspect and gap identifications for own feedback.

Classical survey, geared to quantitative data, is generally associated with interviews where the wording and order of questions are exactly the same for all respondents (Phellas et al., 20I I). Logical validity indicates a rigorous process, such as using a panel of experts to evaluate the validity of a measure (Rubio et al., 2003). Then, re-test trials aim to ensure validity and precision (Gil, 2008).

\section{Data and analysis}

Scaling, that is, the quantification of qualitative measures, should be at the simple end (Jick, 1979), and is considered a primitive triangulatory device (Smith, 1975). In short, words are converted to percentages to represent the popularity of studied points, that is, the frequency of given answers.

There are five triangulation types: data source (collected from distinct persons, places and/or times); researcher (different interviewers, analysers, etc.); theory (distinct theories to explain observations); data type (combination of quantitative and qualitative data); method (observation, interviews, documents, etc.) (Miles and Huberman, 1994).

More than one type could be used in the same study, conferring a plural approach (Meijer et al., 2002). Blending and integrating a variety of data and/or methods, as triangulation demands, may range from simple to complex designs (Jick, 1979). For data collection, time and cost can become limiting factors.

Misuse of inappropriate statistical methods in research, such as by a forced way or without a right application, according to Baker (2016), cannot evince the importance of a finding. The ability to quantitatively assess the limits of the likely margin of error is unique to probability sample surveys, reducing the biased selection (Diamond, 20II). The margin of error delimits the bias from an estimation (Gilliland and Melfi, 20I0).

This paper aimed to evaluate the access by timber housing industry concerning possible incentives and policies from the support of the Brazilian government. The lack of incentives and the governmental disconnection with this industry are expected.

\section{MATERIAL AND METHODS}

Focus and principle of this study

Timber housing production sector in Brazil lacks research, because there are few available studies and no official class associations.

Studies on this field are fully required, both to understand and characterise aspects of this prefabricated construction sector, and promote own development from collected data from such analyses.

Since this information is lacking, survey research emerges as an efficient way, from a sectorial point of view, to obtain data, to verify the current situation and to identify obstacles. A broad research programme was designed, whose survey analysed and characterised the current Brazilian scenario of the timber housing production sector, as detailed De Araujo et al. (2018a,b,c, 20I9). Thus, survey was selected as the methodology to be applied for the proposed sectoral evaluation, because Diamond (20II) suggested that this method is widely used both by business and/or government as it provides economic and systematic ways to gather more information and draw inferences about several individuals. Semi-structured questionnaire was developed by a managing group and personally applied to entrepreneurs from the timber housing sector in Brazil (De Araujo et al., 2018a,b,c, 2019). Four questions were studied here.

\section{Population prospection and survey sampling}

There are no trade associations to represent nationally all timber housing producers as well as rare sectorial information is available. A complete listing of potential producers was the main task for the initial stage of this broad survey. Internet searches focused on finding corporate websites was the methodology required to identify all producers (De Araujo et al., 2018a,b,c, 2019). Following these studies cited, a specific area bordered with a greater local industry concentration was chosen, in view of the lesser costs with the survey methodology. This macro region was formed by $92 \%$ of timber house producers from six states. Entrepreneurs were contacted by phone so as to schedule a formal face-toface interview. Each entrepreneur decided participating in the survey performed, depending randomly on availability or motivation. 


\section{Preparation of the standardised questionnaire}

A wide research was created and performed to support information and discussion about timber housing production sector in Brazil. Many queries were structured to supply possible unknown subjects. First author was the research idealizer and manager, while the last author was the advisor and co-authors contributed in the analyses and design (De Araujo et al., 2018a,b,c, 2019).

This paper considered four questions from this wide research (Table I), which were formulated to understand sectoral condition, targets and obstacles on governmental support. First and third queries were designed with trichotomic responses, while second and fourth queries presented multiple choice answers.

TABLE I Questions and alternatives from applied questionnaire.

\begin{tabular}{|c|c|}
\hline Question & Listed Alternative \\
\hline $\begin{array}{l}\text { I) Does your company count or } \\
\text { counted on any incentive or support } \\
\text { from local government? }\end{array}$ & Yes; no; not informed \\
\hline $\begin{array}{l}\text { 2) If yes in last question, which are } \\
\text { or were the requested support or } \\
\text { incentive examples? }\end{array}$ & $\begin{array}{l}\text { Financing for company; tax } \\
\text { cut; tax exemption; presence } \\
\text { in technological incubator } \\
\text { or park; use of wooden } \\
\text { technique in public buildings }\end{array}$ \\
\hline $\begin{array}{l}\text { 3) Does your company have or } \\
\text { had access to financing for own } \\
\text { improvement or expansion? }\end{array}$ & Yes; no; not informed \\
\hline $\begin{array}{l}\text { 4) If yes in last question, which are or } \\
\text { were requested financing types applied } \\
\text { for own improvement or expansion? }\end{array}$ & $\begin{array}{l}\text { Industrial development; } \\
\text { machinery and equipment } \\
\text { purchase; employment and } \\
\text { income increase; public } \\
\text { banking loans; technological } \\
\text { improvement by research }\end{array}$ \\
\hline
\end{tabular}

Procedures for statistical analysis of data

For those questions with qualitative scope, all responses were converted to percentage, allowing an overall comparison. This strategy respects statement from Gil (2008), whose consideration is required to obtain a rigorous sampling.

Popular tactic in the literature (Miles and Huberman, 1994; Cellard, 2014; Yin, 20I5), data triangulation by documentary analysis was not possible here, because no official reports were available to compare the obtained insights.

High costs of face-to-face interviews and the difficulties to interview busy entrepreneurs by other ways (e-mail, postal, phone, etc.) made it not possible to confirm and endorse those declared responses. Also proposed in the literature (Smith, 1975; Miles and Huberman, 1994; Meijer et al., 2002, among others), the consideration of triangulations from different interviewers and sampled entrepreneurs was not possible. Simultaneous interviews increase the survey costs as well as not all producers have additional businessmen in their direction boards.

For that reason, other triangulation methods were applied in the design of this study with the purpose of confirming truth and reliability of the responses. Then, through prescriptions from Miles and Huberman (1994), data source and type were considered in triangulations. In the data source observation, different places were considered and studied, that is, six different Brazilian states cited

With respect to data source, the interview performance considered many different producers, where more than half of considered sector was evaluated. Data type triangulation was also used, because both qualitative and quantitative responses were obtained to consolidate the observations, which had the further support of some information from corporate websites and available rare reports. Another strategy was inserted to validate the answers, through the triangulation of given responses from different questions.

Two similar responses were given to verify whether interviewees were sharing reliable findings (inserted in second and third queries in Table I), if the company has or had access to its finance.

A margin of error for this simple random sampling was calculated through statistical software. For a margin of error of $5 \%$, Raosoft (2004) prescribed the considerations of a confidence level of $95 \%$ and a response distribution of $50 \%$.

\section{RESULTS}

\section{Population estimation and survey sampling results}

Through face-to-face interviews, survey sampling was obtained from 107 of the 210 companies that form this studied sector (Table 2). Therefore, about $51 \%$ of this sector was analysed in this approach, revealing a $\pm 3.325 \%$ margin of error.

TABLE 2 Obtained estimation and sampling with its margin of error.

\begin{tabular}{ccc}
\hline Result & Value (Producer Unit) & Margin of Error (\%) \\
\hline $\begin{array}{c}\text { Total of Estimated } \\
\text { Producers }\end{array}$ & 210 & - \\
$\begin{array}{c}\text { Sampling of } \\
\text { Interviewees }\end{array}$ & 107 & 6.65 \\
\hline
\end{tabular}

Sources: De Araujo et al. (2018a,b,c, 2019)

Survey results: query I

First question evaluated whether the sampled companies already have and/or had access concerning public incentives and/or support from the Brazilian 
government. The results indicated a basically imperceptible similarity between the responses (Figure I), being within the margin of error obtained for this study (Table 2). In other words, half of this sector declared to have access regarding any kind of governmental incentives.

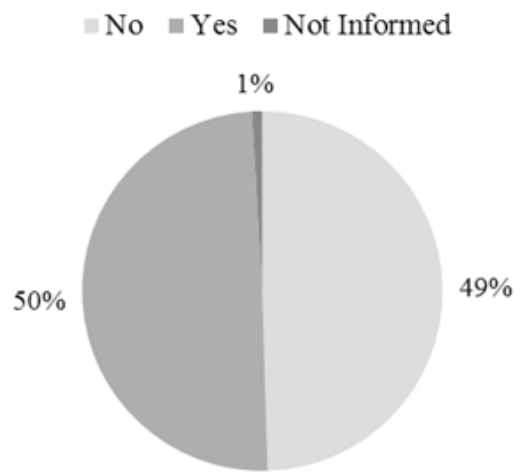

FIGURE I Responses from interviewed producers in query I: any access to government incentive and/or support $(n=107)$.

Survey results: query 2

Within the panorama obtained from question I (Figure I) of governmental incentives, five modalities were found among those present in this sector (Figure 2). In this evaluation, financing for company and use of wood-based techniques in public buildings were the main public tools accessed by the sampled companies. In contrast, incentives about tax exemptions and cuts are not common within this studied sector, suggesting a limited action for industrial development by the Brazilian government.

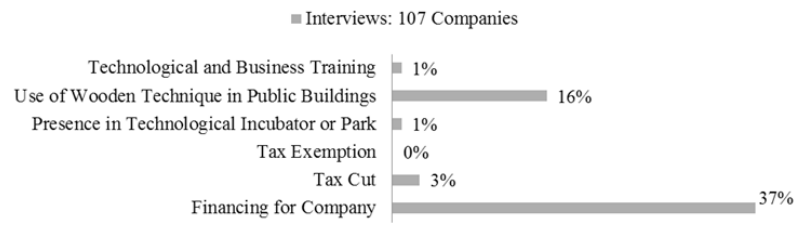

FIGURE 2 Responses from interviewed producers in query 2: government incentives used by sampled producers. $(\mathrm{n}=107)$.

Survey results: query 3

Third question aimed whether each timber housing producer already has and/or had access concerning financing to develop itself. About $37 \%( \pm 3.325 \%)$ of studied population have and/or had any kind of access to public funding (Figure 3), evincing a real contrast concerning economical subsidies from public initiatives.

Survey results: query 4

Then, the access to public funding was analysed through question 4 (Figure 4), indicating the goals which such economical support(s) was/were applied by those sampled producers that declared the utilization of this resource modality (Figure 3).

\section{No $\quad$ Yes $\approx$ Not Informed}

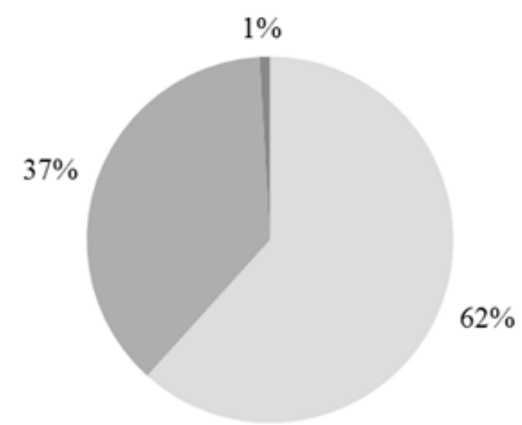

FIGURE 3 Responses from interviewed producers in query 3 : any access to public funding $(n=107)$.

Five modalities were suggested by the interviewees as the main goals for the obtained public funding, among which machinery purchase and industrial development were the most popular mechanisms used in this sector (Figure 4).

Public banking loan was an unpopular way to obtain financial support. Limited amount of perspectives also pointed out a weak integration between this sector and the Brazilian government (Figure 4).

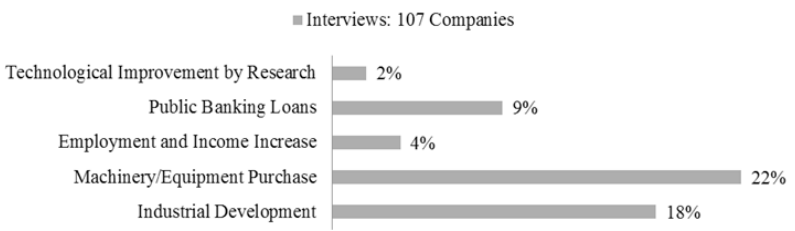

FIGURE 4 Responses from timber housing producers in query 4: public funding used by sampled producers. $(n=107))$.

\section{DISCUSSION}

Population estimation and survey sampling discussions

From sampling and overall estimations (Table 2 ), margin of error was $\pm 3.325 \%$. Compared to the prescriptions of Pinheiro et al. (20II), this survey was fully within the acceptable level and close to ideal point. This fact validated the sampling and results. Final number of sampled entrepreneurs was considered quite representative, because about half of the overall population was observed (107 from 210 producers), and this cited margin of error was statistically low. This representativeness reached a good level in sectoral sampling, similar to what Carvalho et al. (2007) also obtained for their study. 
Survey discussion: initial parallels and data triangulation

Unfortunately, this difference between scenarios (Figures I and 3) suggested that Brazil has not efficiently supported the development of its industry, particularly, those companies from the forestry chain. In short, this timber construction scenario in Brazil contrasted with other developed and developing countries worldwide.

Wood solutions enjoy a strong position in the Finnish construction sector, as wood is widely embraced as building material, benefiting this industry from the highly skilled workforce and prospects for development and investment (Finpro, 2017).

In Finland and Norway, sustainable building is widely explored by means of technology, research and development programs that result in a dominant timber frame housing situation (Tykkä et al., 2010). Development of timber construction in Slovenia and Sweden lies in modern production methods, high prefabrication, and sustainable architecture, as well as partnerships for feedback of experience and team cooperation (Kuzman and Sandberg, 20I7).

There is a demand to re-organize decisionmaking mechanisms, which should be more participative to achieve a good governance and sustainability of the forest resources as suggested by Birben and Gençay (2018). The conception of public policy for timber housing sector in Brazil should satisfy its main demands and solve its main difficulties. Guidelines could create a channel of stimulus for its development.

Slightly over a third of the sampled companies reported on obtaining public financing for their own improvement and/or expansion of production (Figure 3). An identical result to this specific observation was verified in Figure 2, revealing a very precise statement on the part of the sampled producers. This triangulation strategy indicated a reliability of sampling as regards to accuracy of given responses. Further accuracy of the entrepreneur view, this cross-response (or repeated-response) served as a counter-test to ascertain whether the sampled entrepreneurs had a definite understanding of the required topic. Regarding the result importance, their values in both questions were quite low (Figures 2 and 3), due to the visible limited scopes of Brazilian governmental support, which could be greatly expanded in the future.

\section{Survey discussion: query I}

About the access to governmental supports and/ or incentives for the Brazilian timber housing production sector (Figure I), the first question showed that half of the producers had access to public assistances, which were widely detailed in query 2 .

\section{Survey discussion: query 2}

As regards to second question on types of accessed governmental incentives, less than a sixth of the producers had already been able to produce wood-based techniques for some public buildings, thus exhibiting strong restrictions on the public utilisation of such solutions (Figure 2). Considering that timber use in public buildings is an example of tactics to stimulate such housing alternatives, an overall cultural barrier still remains in Brazil as showed Batista (20II), De Araujo et al. (2016a), and other authors. This unpopularity could be attributed to a negative State attitude regarding building maintenance, whereas public authority in Brazil is negligent in this respect. According to Amorim et al. (20I3), few resource allocations for maintenance are real facts in the Brazilian public buildings, evincing negligence from local government. On the other hand, the relocation of low-income residents resulting from public housing redevelopment has attracted a great deal of research attention (Goetz, 20I3). Timber houses could be efficiently used to mitigate housing shortages due to advantages over masonry, such as easy prefabrication, rapid assembly, low waste generation, cleaning, rational use of sustainable materials, etc.

Because of the dominance of masonry and concrete by the large construction contractors as well as visible monopolies of steel and cement companies, there is still no sustainable and healthy space for timber utilisation in traditional houses. For this, incentives are required for the development of smaller sectors as based on timber.

In the Brazilian political and financial context, before the foreign capital markets crisis, Machado and Pedra (2013) noted that several local industries have suffered with low productivity, as well as a relative fall in the public buying power, and then, those tax exemptions emerge as a good incentive method. In view of these chronic problems, tax exemption and tax cut accesses were also studied here.

Tax cuts and exemption have been strategies little explored by the Brazilian government as a way to stimulate these timber housing producers (Figure 2). Due to the development difficulty of the timber construction sector in comparison to traditional masonry and concrete industries, some strategies are required in Brazil. For a greater sectoral competitiveness, Schapiro (2017) has suggested that corrective actions 
are limited to the correction of systemic failures in the business environment, for example, where the Brazilian government has established for the automotive sector. However, these strategies would need to be temporary to avoid a state-dependent industry.

Lastly, those incentives for technological and business training and access to technological incubators and parks were almost imperceptible, given the low values given by the studied sector (Figure 2). The expansion of these incentives on the technological environment should be widely encouraged by government.

Instruments of industrial and technological innovation are organised by sectors, due to the sectoral nature of knowledge from political agents (Tironi, 2005). For the modernisation of forest and timber industrial parks in Brazil, Nielsen (20I0) identified that new public policies need to include credit lines for machinery acquisition with the premises of improvements in productivity and product finishing.

For this, unprecedented stimuli need to be created and well-explored for timber housing, whereas the present incentives are only focused on traditional contractors for the production of consolidated solutions in masonry or concrete.

\section{Survey discussion: query 3}

Like query I (Figure I), the responses from the third question about the access to public funding for expansion and improvement of production capacity of this sector (Figure 3 ) evinced that most of the producers do/did not access those solutions for technological and production stimuli. Such solutions were widely detailed in query 4.

\section{Survey discussion: query 4}

In Brazil, the National Bank of Regional Development (BNDES) acts as financial resource provider, from medium to long term, for economic and social developments, supported by credit lines with several aims and different names as "Finem", "Finame”, "Finance", "Automático", etc. (Quaglio and Paiva, 2017). In relation to public funding evaluation of the fourth question (Figure 4), the utilisation of machinery/equipment purchase - whose financial tool is known by "Finame" - was the most used alternative, reaching about a fifth of obtained sampling. Financing to stimulate, expand and create production practices - for example, BNDES's credits - became the second greater way to obtain public loans, whereas such examples were accessible to almost a fifth of studied producers.
Conventional public loans obtained directly from federal or regional state banks emerged as the third most common funding for industrial purposes.

In order to support and benefit any small and micro entrepreneurs, small and micro companies as well as other compact businesses, the Brazilian government instituted the "PROGER", that is, a local program of job and income generation for people without access to traditional loans (Cardoso et al., 2002). Regarding this strategy for stimuli on small and micro companies, low access to funding for employment evinced its unpopularity and low accessibility (Figure 4).

Research funding for industrial development through creation of new business and/or new technologies and innovative products was revealed to be unpopular in this studied sector (Figure 4). As some wood-based techniques present strong embedded technology, this strategy must be vigorously exploited by public power in Brazil, with the objective of attracting new projects for the industrial production of standardised sustainable houses. Still, De Araujo et al. (20I6b) indicated that strong industrialisation with prefabrication of timber houses should be the focus of attention in the near future, depending on the depth of housing deficit in underdeveloped and developing nations.

\section{Survey discussion: final comments}

Despite the presence of some beneficial solutions listed in the Figures 2 and 4, sectoral incentives are largely unpopular and/or restricted to few businesses.

The dissemination and popularisation of these existing strategies should be the main focus of the Brazilian government, including the permanent access to incentives by all wood-based housing producers, which would consequently generate expansion of their industrial plants and improvements in machinery and manufacture technology.

There are actions oriented towards transformation of comparative advantages, characterizing in a State focussed on the promotion of innovations (Schapiro, 2017).

Fares et al. (2015) noted that policies and plans should consider commitments between the ability of forests to store carbon and produce timber products as well as other ecosystem services. From this sustainable mind, De Araujo et al. (2017) stated that stimuli for forestand timber-based sectors are required, considering that many companies from the timber chain still did not reach market consolidation. Such strategy could be inspired by existing projects. In their project for European markets, Hughes et al. (2016) defined as planned steps the policy 
and decision makers in the activity in the design of research initiatives, with alignment of the necessities of policy makers and building codes with the research outcomes and the new specific knowledge resulting.

The results of this survey are in agreement with the situation described by Chan and Chan (20II) as a moment for dedication, by construction researchers and industry practitioners, of efforts to research and dissemination of advances in technology. Such results also agreed with those challenges of the forest products industry in the United States, which are characterized by few incentives from industry culture and policy as suggested by Orozco et al. (2013). Thereby, the hypothesis was proven due to the disconnection of local government on timber housing, justified by limited incentives.

\section{CONCLUSIONS}

Despite the existence of some government policies and incentives for timber housing production sector, their scopes are very limited in Brazil. Strategies have been idealised for whole national industry, that is, they are generically accessible to every industrial segment, without favouring cleaner industry and those businesses based on sustainable materials, i.e., wood. Thus, public support is necessary for this sector.

Tax incentive and public funding to develop businesses is not accessible to all companies. There is the immediate need for an expansion of this financial access, especially to small producers, who usually have greater difficulties in expanding their production capacity and making technical improvements.

Expansion of timber housing for future public construction would enable greater knowledge and engagement by society with these more sustainable options, softening the present negative cultural barrier in Brazil.

These public supports should be focussed stimulating the producers as well as on attracting further entrepreneurs to this analysed sector. In short, new businesses and local production would be essentially encouraged. Due to the content novelty, the results and discussions could contribute to new public policies to develop this sector.

\section{REFERENCES}

AMORIM, G. M.; QUINTÃO, E. C. V.; MARTELLI JÚNIOR, H.; BONAN, P. R. F. Prestação de serviços de manutenção predial em estabelecimentos assistenciais de saúde. Ciência \& Saúde Coletiva, v. 18, n. I, p. 145-I58, 2013.
BACHA, C. J. C. O sistema agroindustrial da madeira no Brasil. Revista Econômica do Nordeste, v. 32, n. 4, p. 975-993, 2001.

BAKER, M. Statisticians issue warning on $\mathrm{P}$ values. Nature, v. 53I, n. 7593, p. I5I-I5I, 2016.

BARBU, M. C.; PAULITSCH, M. Development of wood-based products worldwide. ProLigno, v. II, n. 4, p. I04-109, 2015.

BATISTA, E. M.; GHAVAMI, K. Development of Brazilian steel construction. Journal of Constructional Steel Research, v. 6I, n. 8, p. 1009-1024, 2005.

BATISTA, F. D. A casa de madeira: um saber popular. In: A casa de araucária: arquitetura da madeira em Curitiba. v. 2. Instituto Arquibrasil, 20I I. p. I-I0I.

BERR, L. R.; ECHEVESTE, M. E. S.; LORENZI, L. S.; FORMOSO, C. T. Indicador de falhas de qualidade na percepção dos usuários de habitação de interesse social. Ambiente Construído, v. I5, n. 4, p. 19-35, 2015.

BHATTACHERJEE, A. Social science research: principles, methods, and practices. 2nd ed. CreateSpace, 20I2. p. I-I56.

BIRBEN, Ü.; GENÇAY, G. Public interest versus forests. Cerne, v. 24 , n. 4 , p. $360-368,2018$.

CARDOSO, L. C.; FAÇANHA, L. O., MARINHO, A. Avaliação de programas sociais (PNAE, PLANFOR, PROGER): eficiência relativa e esquemas de incentivo. Ipea, 2002. p. I-44.

CARVALHO, R. M. M. A.; LIMA, A. A. T. F. C.; MENDES, L. M.; SANTOS, C. A.; OLIVEIRA, J. M.; RESENDE, J. L. P.; NOCE, R. Tipologia da indústria de base florestal do estado de Minas Gerais. Cerne, v. I3, suplemento, p. 73-80, 2007.

CARVALHO, R. M. M. A.; SOARES, T. S.; VALVERDE, S. R. Caracterização do setor florestal: uma abordagem comparativa com outros setores da economia. Ciência Florestal, v. I5, n. I, p. I05-I I8, 2005.

CASTRO, M. L.; VON KRUGER, P. G. Unidades de seleção tecnológica e inovação na construção habitacional no Brasil. Ambiente Construído, v. 13, n. 3, p. 217-233. 2013.

CELLARD, A. A análise documental. In: POUPART, J.; DESLAURIERS, J. P.; GROULX, L. H.; LAPERRIĖRE, A.; MAYER, R.; PIRES, A. P. (Orgs.). A pesquisa qualitativa: enfoques epistemológicos e metodológicos. Vozes, 2014. p. I-464.

CHAN, D. W. M., CHAN, A. P. C. Public housing construction in Hong Kong: a review of its design and construction innovations. Architectural Science Review, v. 45, n. 4, p. 349-359, 2011 .

DE ARAUJO, V.; NOGUEIRA, C.; SAVI, A.; SORRENTINO, M.; MORALES, E.; CORTEZ-BARBOSA, J.; GAVA, M.; GARCIA, J. Economic and labor sizes from the Brazilian timber housing production sector. Acta Silvatica et Lignaria Hungarica, v. 14, n. 2, p. 95-106, 2018 a. 
DE ARAUJO, V. A.; CORTEZ-BARBOSA, J.; GARCIA, J. N. GAVA, M.; LAROCA, C.; CÉSAR, S. F. Woodframe: light framing houses for developing countries. Revista de la Construcción, v. 15, n. 2, p. 78-87, 2016 a.

DE ARAUJO, V. A.; GARCIA, J. N.; CORTEZ-BARBOSA, J.; GAVA, M.; SAVI, A. F.; MORALES, E. A. M.; LAHR, F. A. R.; VASCONCELOS, J. S.; CHRISTOFORO, A. L. Importância da madeira de florestas plantadas para a indústria de manufaturados. Pesquisa Florestal Brasileira, v. 37, n. 90, p. $189-200,2017$.

DE ARAUJO, V. A.; GUTIÉRREZ-AGUILAR, C. M.; CORTEZBARBOSA, J.; GAVA, M.; GARCIA, J. N. Disponibilidad de las técnicas constructivas de habitación en madera, en Brasil. Revista de Arquitectura, v. 21, n. I, p. 68-75, 2019.

DE ARAUJO, V. A.; LIMA JR., M. P.; BIAZZON, J. C.; VASCONCELOS, J. S.; MUNIS, R. A.; MORALES, E. A. M.; CORTEZ-BARBOSA, J.; NOGUEIRA, C. L.; SAVI, A. F; SEVERO, E. T. D.; CHRISTOFORO, A. L.; SORRENTINO, M.; LAHR, F. A. R.; GAVA, M.; GARCIA, J. N. Machinery from Brazilian wooden housing production: size and overall obsolescence. BioResources, v. I3, n. 4, p. 8775-8786, 20 I8b.

DE ARAUJO, V. A.; VASCONCELOS, J. S.; CORTEZ-BARBOSA, J.; MORALES, E. A. M.; GAVA, M.; SAVI, A. F.; GARCIA, J. $\mathrm{N}$. Wooden residential buildings - a sustainable approach. Bulletin of the Transilvania University of Brasov Series II: Forestry • Wood Industry • Agricultural Food Engineering, v. 9 , n. 2, p. 53-62, 2016b.

DE ARAUJO, V. A.; VASCONCELOS, J. S.; MORALES, E. A. M.; SAVI, A. F.; HINDMAN, D. P.; O'BRIEN, M. J.; NEGRÃO, J. H. J. O.; CHRISTOFORO, A. L.; LAHR, F. A. R.; CORTEZBARBOSA, J.; GAVA, M.; GARCIA, J. N. Difficulties of wooden housing production sector in Brazil. Wood Material Science \& Engineering, p. I-10, 2018c.

DIAMOND, S. S. Reference guide on survey research. In: FEDERAL JUDICIAL CENTER. Reference manual on scientific evidence. 3rd ed. The National Academies Press, 201 I. p. 359-423.

FARES, S.; MUGNOZZA, G. S.; CORONA, P.; PALAHÍ, M. Five steps for managing Europe's forests. Nature, v. 5 I9, n. 7544, p. 407-409, 2015

FINPRO. Building blocks for sustainable success. Invest in Finland, 20I7. p. I-I.

GIL, A. C. Métodos e técnicas de pesquisa social. 6th. ed. Atlas, 2008, p. I-200.

GILLILAND, D., MELFI, V. A note on confidence interval estimation and margin of error. Journal of Statistics Education, v. 18, n. I, p. I-8, 2010.

GOETZ, E. W. Too good to be true? The variable and contingent benefits of displacement and relocation among low-income public housing residents. Housing Studies, v. 28, n. 2, p. 234-252, 2013.
HUGHES, M.; KALAMEES, T.; NIEMZ, P. Massive wood house industry: 2016 carbon capture \& sustainability report. ImtInstitute, 2016. p. I-9.

IBÁ. As árvores plantadas e seus múltiplos usos. Ibá, 20I7. p. I-4.

IBÁ. Relatório 2019. Ibá, 2019. p. 1-79.

JICK, T. D. Mixing qualitative and quantitative methods: triangulation in action. Administrative Science Quarterly, v. 24, n. 4, p. 602-6II, 1979.

KUZMAN, M. K.; SANDBERG, D. Comparison of timberhouse technologies and initiatives supporting use of timber in Slovenia and in Sweden - the state of the art. iForest: Biogeosciences and Forestry, v. 10, p. 930-938, 2017

LIN, J.; CHANG, H. Should industrial policy in developing countries conform to comparative advantages or defy it? A debate between Justin $\mathrm{Lin}$ and $\mathrm{Ha}$ Joon Chang. Development Policy Review, v. 27, n. 5, p. 483-502, 2009.

LONGUE JR., D., COLODETTE, J. L. Importância e versatilidade da madeira de eucalipto para a indústria de base florestal. Pesquisa Florestal Brasileira, v. 33, n. 76, p. 429-438, 2013.

MACHADO, A. A. L.; PEDRA, A. S. Redução de alíquota do imposto sobre produtos industrializados para automóveis: reflexões sobre uma sociedade (in)sustentável, o princípio da seletividade tributária e o dever fundamental de pagar tributos. Revista da Ajuris, v. 40, n. I30, p. 55-72, 2013.

MACHADO, D. D. P. N.; CARVALHO, C. E. Traços culturais de pequenas empresas do setor madeireiro. Revista Ciências Administrativas, v. 12, n. I, p. 16-24, 2006.

MEIJER, P. C.; VERLOOP, N.; BEIJAARD, D. Multi-method triangulation in a qualitative study on teachers' practical knowledge: an attempt to increase internal validity. Quality \& Quantity, v. 36, p. I45-167, 2002.

MILES, M. B.; HUBERMAN, A. M. Qualitative data analysis: an expanded sourcebook. Sage, 1994. p. I-338.

MURARA JR., M. I.; ROCHA, M. P.; TRUGILHO, P. F. Estimativa do rendimento em madeira serrada de pinus para duas metodologias de desdobro. Floresta e Ambiente, v. 20, n. 4, p. 556-563, 2013

NIELSEN, I. R. Estudo de oportunidades de negócios florestais: papel e celulose; painéis de madeira; madeira serrada. UNDP/SAE, 20I0. p. I-258.

OLIVEIRA, M. B.; SILVA, J. R. M.; HEIN, P. R. G.; LIMA, J. T. Establishment of quality classes for hardwood floorings by simulated use. Cerne, v. 25, n. I, p. 105-109, 2019.

OROZCO, N.; HANSEN, E.; KNOWLES, C.; LEAVENGOOD, $S$. Oregon's forest sector innovation system: an investigation towards advanced performance. The Forestry Chronicle, v. 89, n. 2, p. 225-234, 2013. 
PHELLAS, C. N.; BLOCH, A.; SEALE, C. Interviews, questionnaires and observation. In: SEALE, C. Researching society and culture. Sage Publications, 20 I I. p. I8I-205.

PINHEIRO, R. M.; CASTRO, G. C.; SILVA, H. H.; NUNES, J. M. G. Pesquisa de mercado. Editora FGV, 20 I I. p. I-I54.

QUAGLIO, G. M.; PAIVA, C. C. A questão regional e o BNDES: uma análise da conformidade entre a atuação do Banco e a Política Nacional de Desenvolvimento Regional (PNDR). Economia e Sociedade, v. 26, n. 2, p. 337-368, 2017.

RAOSOFT. Raosoft sample size calculator. 2004. Available at: raosoft.com/samplesize.html. Accessed in: July Ist 2019.

RIBEIRO, J. A. Z. M. T.; MOREIRA, T. A. A política fundiária nos planos locais de habitação: entre a demanda terra e o direito de propriedade. Ambiente Construído, v. 14, n. 4, p. $217-232,2014$.

RUBIO, D. M.; BERG-WEGER, M.; TEBB, S. S.; LEE, E. S.; $\mathrm{RAUCH}$, S. Objectifying content validity: conducting a content validity study in social work research. Social Work Research, v. 27, n. 2, p. 94-104, 2003.

SANTOS, M. P.; AGUILAR, M. T. P. Painéis de madeira como vedação vertical em construções. Cadernos de Arquitetura e Urbanismo, v. I4, n. I5, p. 242-263, 2007.

SCHAPIRO, M. O estado pastor e os incentivos tributários no setor automotivo. Revista de Economia Política, v. 37, n. 2, p. 437-455, 2017.
SMITH, H. W. Strategies of social research: the methodological imagination. Prentice Hall, 1975. p. I-423.

STEPHENS, M. L., GRIST, P. Market failure for plantations: past experiences and emerging trends for delivering wood production and ecosystem services in Australia. International Forestry Review, v. 16, n. 2, p. 205-2। 5, 2014.

TIRONI, L. F. Política de inovação tecnológica escolhas e propostas baseadas na Pintec. São Paulo em Perspectiva, v. 19, n. I, p. 46-53, 2005.

TOLLEFSON, J. Wood grows up. Nature, v. 545, p. 280282, 2017.

TYKKÄ, S.; MCCLUSKEY, D.; NORD, T.; OLLONQVIST, P.; HUGOSSON, M.; ROOS, A.; UKRAINSKI, K.; NYRUD, A. Q.; BAJRIC, F. Development of timber framed firms in the construction sector - Is EU policy one source of their innovation? Forest Policy and Economics, v. 12, n. 3, p. 199206, 2010.

XIA, B., O'NEILL, T., SKITMORE, M., CHEN, Q. Perceived obstacles to multi-storey timber-frame construction: an Australian study. Architectural Science Review, v. 57, n. 3 , p. 169-176, 2014.

YIN, R. K. Estudo de caso: planejamento e métodos. 4th. ed. Bookman, 20I5. p. I-320. 